\title{
Duyguları Yönetme Becerileri Eğitim Programının Çocukların Duyguları Yönetme ve Bakış Açısı Alma Becerilerine Etkisinin İncelenmesi*
}

Türk Eğitim Bilimleri Dergisi Makale Türü: Araştırma Makale Geliş Tarihi: 25.08.20 Makale Kabul Tarihi: 21.10.20 Makale Yayın Tarihi: 28.12.20 ORCID: 0000-0002-0238-2714, 0000-0003-2965-7017

\author{
Dicle Cantekin ${ }^{1}$ Gülümser Gültekin
}

Akduman $^{2}$

\section{Öz}

$\mathrm{Bu}$ araştırma, okul öncesi dönem çocuklarının “Duyguları Yönetme Becerileri Eğitim Programının (DYBEP)" çocukların duyguları yönetme ve bakış açısı alma becerisine etkisini incelemek amacıyla yapılmıştır. Araştırmada veri toplama aracı olarak çocuk ve aile genel bilgi formu, Aslan ve Köksal Akyol (2016) tarafından geliştirilen Çocuklar için Bakış Açısı Alma Testi (ÇBT), TÜBITTAK tarafından desteklenen Okul Öncesi Sosyal Beceri Değerlendirme Ölçeğinin (OSBED) duyguları yönetme becerileri alt ölçeği kullanılmıştır. Araştırmanın çalışma grubuna 2019-2020 eğitim öğretim yılında, Milli Eğitim Bakanlığına bağlı bir anaokulunun iki sınıfından 20 deney, 20 kontrol olmak üzere 40 çocuk dahil edilmiştir. Deney ve kontrol grubuna ön testler uygulandiktan sonra, deney grubuna haftada iki gün, 12 haftada 24 oturum şeklinde Duyguları Yönetme Becerileri Eğitim Programı (DYBEP) uygulanmıştır. Uygulama sonrasında deney ve kontrol gruplarına son test uygulaması ve 5 hafta sonra kalıcılık testi yapılmıştır. Elde edilen bulgular sonucunda; deney grubuna uygulanan Duyguları Yönetme Becerileri Eğitimi Programının, duyguları yönetme becerileri üzerinde etkili olduğu ve bu etkinin kalıcı olduğu sonucuna ulaşılmıştır. Bakış açısı alma becerilerine ilişkin sonuçlar incelendiğinde, eğitim programının etkili olduğu ve bu etkinin kalıcı olduğu saptanmıştır. Araştırmanın sonucunda deney grubundaki çocukların duygusal bakış açısı alma ve toplam puanlarında istatistiksel olarak anlamlı bir farklılığın bulunduğu saptanmıştır.

Anahtar Sözcükler: Okul öncesi eğitim, Duyguları yönetme becerileri, Bakış açısı alma, Okul öncesi eğitim programı

\begin{abstract}
This research was carried out to investigate the effect of the "Emotion- Management Skills Training Program" of preschool children on their ability to manage emotions and take perspective. The child and family general information form, the Children's Perspective Taking Test prepared by Aslan and Köksal Akyol (2016) and the emotion management skills subscale of the Preschool Social Skills Assessment Scale supported by TÜBITTAK were used as data collection tools. The study group of the research consists of two classes, which is affiliated to the Ministry of National Education in the 20192020 academic year. The experimental group comprises 20 children and the control group consists of 20 children, totally 40 children. Preliminary tests were applied to the experimental group and the control group. After the program implementation in 24 sessions in 12 weeks for two days a week, the post-test was applied to the same groups. After the pre-tests were applied to the experimental and
\end{abstract}

\footnotetext{
*Bu çalışma Prof. Dr. Gülümser Gültekin Akduman danışmanlığında Dr. Dicle Cantekin tarafından hazırlanan doktora tezinden üretilmiştir.

${ }^{1}$ Dicle Cantekin, Dr., Milli Eğitim Bakanlığı, dicleakydn@hotmail.com

2 Gülümser Gültekin Akduman, Prof. Dr., Gazi Üniversitesi, gulumsergultekin@yahoo.com
} 
control groups, the Emotion Management Skills Training Program (DYBEP) was applied to the experimental group two days a week, 24 sessions in a total of 12 weeks. After that, the post-test was applied to the experimental and control groups and the permanence test was performed five weeks later. As a result of the findings, it was concluded that the Emotion Management Skills Training Program applied to the experimental group was effective on emotion management skills. Indeed when the results regarding perspective-taking skills were examined, it was found that the training program was effective and this effectiveness is permanent. Finally it was found that there was a statistically significant difference in the emotional perspective-taking and total scores of the children in the experimental group.

Keywords: Preschool education, Emotion management, Take perspective, Preschool education program

\section{Giriş}

Kişinin kendi duygusal ifadelerini kontrol etme ve stratejik olarak kullanma yeteneği, bir çocuğun büyüyen sosyo-duygusal yeterliliğinde önemli bir gelişimsel adımdır (Saarni, 1999; Lewis, 1998). Özellikle okul öncesi dönem, çocukların duygu düzenleme becerilerinin hızla geliştiği ve kendi duygularının yanında başkalarının da duygularını anlamaya başladığı kritik bir dönemdir (New \& Cochran, 2007).

Çocukların erken yaşlardan itibaren kazanacakları sosyal-duygusal gelişim becerileri daha sonraki yılların duygusal davranışlarının temelini oluşturacaktır. Nitekim yapılan araştırmalarda erken yaşlarda duyguları tanıma, anlama ve düzenleme gibi duygusal beceriler ile ilgili yaşanan problemlerin, çocuklarda yıkıcı davranış problemleri ile ilişkili olduğunu göstermektedir. Aynı zamanda erken çocukluk döneminde duyguları yönetme becerilerinin daha az kullanılmasının ergenlik döneminde sorunlara neden olduğu bildirilmektedir (Caselman \& Self, 2008; Trentacosta \& Shaw, 2009). Ashiabi (2000) uygun duygu düzenlemesinin akranlarla olumlu ilişkiler geliştirmede en önemli unsur olduğunu ve duyguların ifade ediliş biçiminin sosyal yeterliliğin bir göstergesi ya da ölçütü olarak görülebileceğini ifade etmiştir.

Kişiliğin temellerinin atıldığı erken çocukluk dönemi, duyguları yönetme becerilerinin kazandırılmasında ilgili eğitimin verileceği en verimli yıllardır. Bu nedenle okul öncesi öğretmenleri eğitim ortamlarında çocukların duygularını nasıl yöneteceklerini, başkalarının bakış açısını anlamayı, sosyal ilişkileri başlatmayı ve sürdürmeyi öğretmek için çaba sarf ederler (New \& Cochran, 2007).

Bakış açısı alma, bir başkasının içinde bulunduğu çevrede ne düşündüğünü, nasıl hissettiğini ve nasıl davrandığını çıkarma sürecidir (Sessa, 1996). Bakış açısı alma, sosyal etkileşimlerde çok önemlidir. Çünkü diğer insanların düşüncelerini öngörmeyi kolaylaştırır (Dixon \& Moore, 1990). Yapılan araştırmalar, bakış açısı alma ve sosyal becerilerin birbirleriyle ilişkili olduğunu göstermektedir. Bakış açısı almada daha iyi olan çocukların, akranları ile sembolik oyun sırasında, rolleri idare etmede daha başarılı olduklarını belirtmektedir. Bakış açısı almada daha başarılı olan 
çocuklar, öfke kontrolü sağlamada ve sosyal sorunlar karşısında daha uygun davranışlar sergilemektedirler (Astington \& Jenkins, 1995; Strayer \& Robert, 2004; Tan-Niam, Wood, \& O'Malley, 1998).

Bakış açısı alma becerisi, diğer insanların duygularını tanımayı ve buna göre tepki vermeyi temel alır (Staub, 1990). Çocuklar, başkalarının bakış açısını alabilme kapasitelerini geliştirdikçe başka insanların duygularını bilebilirler. Bu beceri aracılı̆̆ıyla, kişiler belli bir olay ya da obje ile ilgili algılarını, düşüncelerini ya da duygularını tahmin ederek hareketlerini düzenleyebilirler (Moll \& Meltzoff, 2011). Bu bağlamda, çocukların bakış açısı alma becerileri ile duyguları yönetme becerilerinin sosyal-duygusal davranışlar üzerinde farklı etkileri ortaya çıkabilmektedir. Örneğin: Bazı araştırmalar, bakış açısı almanın başkalarının duygularını anlama ve pro-sosyal davranışları yürütme gibi sosyal davranışlarda önemli olduğunu ortaya koymaktadır (Oswald, 2010; Roberts \& Strayer, 1996; Weil, Hayes, \& Capurro, 2011). Duyguları yönetme ve bakış açısı alma becerisi çocukların ruhsal ve toplumsal gelişiminde önemli rol oynamaktadır. Okul öncesi dönem, çocukların duygularını tanımayı, ifade etmeyi ve duyguları kontrol edip ayarlamayı öğrenmesi için temel oluşturur.

Sosyal duygusal becerileri geliştirmeyi amaçlayan okul öncesi eğitim programlarının duygusal gelişimi olumlu destekleyebileceği düşünülmektedir. Sosyal duygusal öğrenme programları çocukların ve yetişkinlerin duyguları anlama ve yönetme, olumlu hedefler belirleme ve bunlara ulaşma, empati gösterme, olumlu ilişkiler kurma gibi becerilerini destekleyebilir. Programlar kısa vadede çocukların duygularını ve davranışlarını kontrol etmelerini sağlarken, uzun vadede okula ve öğrenmeye karşı olumlu tutum geliştirmelerini sağlamaktadır (Durlak, Weissberg, Dymnicki, Taylor \& Schellinger, 2011; Greenberg, vd., 2003). Sosyal duygusal programlar çocukların, daha fazla engelleyici kontrol, planlama ve set değiştirme gibi bilişsel işlevlerini etkileyebileceği ileri sürülmektedir (Greenberg, 2006). Bu eğitim programları, özenli öğrenme ortamları oluşturarak, sınıf yönetimini ve öğretim uygulamalarını geliştirerek öğrencilerin sosyal-duygusal gelişimini teşvik eder (Schaps, Battistich, \& Solomon, 2004). Programların etkili olmasında sistemli gerçekleştirilmesi, etkin öğrenmeyi teşvik etmesi, örtük olması ve sosyal duygusal becerileri geliştirmeye odaklanması gibi özellikler bulunmaktadır (Durlak, Weissberg, Dymnicki, Taylor \& Schellinger, 2011).

Yurt içinde yapılan araştırmalar incelendiğinde duygu düzenleme becerilerini çocuğun mizacı, ebeveyn davranışları, yönetici işlev becerileri, saldırganlık düzeyleri, duyguları ifade etme becerileri, bağlanma şekilleri ve çeşitli değişkenler açısından incelenmiştir (Akbaba, 2017; Bozkurt Yükçü \& Demircioğlu; 2017; Ersan, 2017; Öztemür, 2018; Ural, Güven, Sezer, Efe Azkeskin \& Yılmaz, 2015). Sosyal beceri eğitim programlarından ayrı geliştirilen DYBEP, çocukların daha yüksek duygu bilgisi becerilerine sahip olabilmelerini öğretmenleri ve akranları ile daha sağliklı iletişim kurabilmelerini kolaylaştırabilir. Bu programlar sayesinde, çocukların duygusal farkındalığı ve dürtü kontrolü 
geliştirilebilir. Çocukların geleceklerini ve birbirleriyle iletişimlerini önemli oranda etkileyebilen bu yeteneklerin/becerilerin geliştirilmesi için, eğitim programlarının geliştirilmesi ve uygulanması oldukça önemli olabilir. Bu bağlamda, çocuğun duygusal yönden gelişmesi, duygulara yönelik eğitim programları ve öğrenme ortamlarının düzenlenmesi önemli katkı sağlayabilir. Bu düşünceden hareketle araştırmada, DYBEP’nin okul öncesi çocukların duyguları yönetme ve bakış açısı alma becerileri üzerindeki etkisi incelenmiştir.

\section{Yöntem}

\section{Araştırmanın Modeli}

Araştırmada, ön test-son test-kontrol gruplu deneysel desen kullanılmıştır. Deney grubundaki çocuklara verilen eğitimin etkisini ölçmek amacı ile çocuklara ön test-son test ve kalıcılık testi uygulanmıştır.

\section{Çalışma Grubu}

Araştırmanın çalışma grubu, 2019-2020 eğitim-öğretim yılı Ankara ili Çubuk İlçesi'nde, Millî Eğitim Bakanlığına bağlı bir anaokuluna devam eden deney grubu 20 çocuk ve kontrol grubu 20 çocuk olmak üzere 40 çocuktan oluşmaktadır. Araştırmanın nicel verilerinin toplandığı katılımcı çocuklara

\begin{tabular}{lccccccc}
\hline & \multicolumn{2}{c}{$\begin{array}{c}\text { Deney } \\
\text { Grubu }\end{array}$} & $\begin{array}{c}\text { Kontrol } \\
\text { Grubu }\end{array}$ & Toplam \\
\hline & $\mathrm{n}$ & $\%$ & $\mathrm{n}$ & $\%$ & $\mathrm{n}$ & $\%$ \\
\hline
\end{tabular}

ilişkin bilgiler Tablo 1'de verilmiştir.

Tablo 1. Deney ve Kontrol Grubundaki Çocuklara Ait Demografik Bilgiler 


\begin{tabular}{llcccccc}
\hline \multirow{2}{*}{ Cinsiyet } & Kız & 10 & 50,00 & 7 & 35,00 & 17 & 42,50 \\
& Erkek & 10 & 50,00 & 13 & 65,00 & 23 & 57,50 \\
\hline \multirow{3}{*}{ Kardeş Sayıları } & Kardeşi yok & 0 & 0 & 2 & 10,00 & 2 & 5,00 \\
& Bir kardeş & 3 & 15,00 & 13 & 65,00 & 16 & 40,00 \\
& İki kardeş & 15 & 75,00 & 5 & 25,00 & 20 & 50,00 \\
& Üç kardeş & 2 & 10,00 & 0 & 0 & 2 & 5,00 \\
\hline Ailede kaçıncı çocuk & İlk çocuk & 11 & 55,00 & 13 & 65,00 & 24 & 60,00 \\
& İkinci çocuk & 5 & 25,00 & 3 & 15,00 & 8 & 20,00 \\
& Üçüncü çocuk & 4 & 20,00 & 4 & 20,00 & 8 & 20,00 \\
\hline Daha Önceden Okul Öncesi & Okul öncesi eğitim & 12 & 60,00 & 13 & 65,00 & 25 & 62,50 \\
Eğitimden Yararlanma & aldı & & & & & & \\
Durumu & Okul öncesi eğitim & 8 & 40,00 & 7 & 35,00 & 15 & 37,50 \\
& almadı & & & & & & \\
\hline
\end{tabular}

Tablo 1'de yer alan, çocukların cinsiyete göre dağılımları incelendiğinde, deney grubundaki çocukların \%50'sinin kız, \%50'sinin ise erkek olduğu görülmektedir. Kontrol grubundaki çocukların \%35'inin kız, \%65'inin ise erkek olduğu görülmektedir. Deney grubundaki çocukların \%15'nin bir kardeşinin olduğu, \%75'inin ise iki kardeşinin olduğu ve \%10'nun üç kardeşinin olduğu görülmüştür. Kontrol grubunda çocukların \%10'nun kardeşi olmadığı, \%65'inin ise bir kardeşinin olduğu, \%25'nun iki kardeşinin olduğu görülmektedir. Deney grubundaki çocukların \%55'i ilk çocuk, \%25'i ikinci çocuk ve \%20'nin üçüncü çocuk olduğu görülmüştür. Kontrol grubunda çocukların \%65'inin ilk çocuk, \%15'inin ikinci çocuk ve \%20'sinin üçüncü çocuk olduğu görülmektedir. Deney grubundaki çocukların \%60'ının okul öncesi eğitim almış iken, \%40'ının ise okul öncesi eğitim almadığı görülmektedir. Kontrol grubundaki çocukların ise, \%65'inin okul öncesi eğitim aldığı, \% 35'sinin ise daha önce okul öncesi eğitim aldığg görülmüştür.

\section{Veri Toplama Araçları}

Araştırmada veri toplamak için; anne, baba ve çocukların demografik bilgilerini elde etmek amacıyla hazırlanan Çocuk ve Aile Bilgi Formu, okul öncesine devam eden çocukların sahip olduğu duygularını yönetme becerilerini belirlemek için Okul Öncesi Eğitimde Sosyal Beceri Değerlendirme Ölçeği (OSBED) Duyguları Yönetme Becerileri Alt Ölçeği ve bakış açılarını belirlemek için Bakış Açısı Alma Ölçeği kullanılmıştır.

\section{Çocuk ve Aile Genel Bilgi Formu}

Çocuklarının yaşı, cinsiyeti, kardeş sayısı, doğum sırası ve daha önce okul öncesi eğitim kurumuna gitme durumları, anne ve babaların, yaş, eğitim durumu, mesleği ve aile tipleri bilgileri tespit etmeye yönelik çoktan seçmeli sorular yer almaktadır.

\section{Duyguları Yönetme Becerileri Alt Ölçeği}


Ömeroğlu ve arkadaşları, (2014) tarafından geliştirilen TÜBİTAK tarafından desteklenen, “Okul Öncesi Sosyal Beceri Destek Projesi (OSBEP)” kapsaminda Okul Öncesi Sosyal Beceri Değerlendirme Ölçeği (OSBED)-Duyguları Yönetme Becerileri Alt Ölçeği kullanılmıştır. Beşli derecelendirilmiş likert tipi bir ölçektir. Duyguları yönetme becerileri, duyguları tanıma, yönetme ve kontrol etme yetileridir. Bu yetiler, duygularını başkalarını rahatsız etmeden gösterme, engellenme durumuyla baş etme, hatalarıyla baş etme, başkalarının duygularını anlama, baskı altında sakin kalma, alay etmeyle baş etme, hayır cevabını kullanma, isteğini erteleme, tepki vermeden önce düşünme, hayır cevabını kabul etme, hakkını koruma ve kendiliğinden çözülecek sorunları görmezden gelme becerileri olmak üzere toplam 12 maddeden oluşmaktadır. Duygularını Yönetme Becerileri ölçekte 3849 numaralı maddeler arasında yer almaktadır.

OSBED öğretmen formu için 5 yaş grubu için .88 ile .96 aralığında değiştiği belirlenmiştir. Bu sonuç, ölçeğin iç tutarlılık anlamında güvenirliğe sahip olduğunu göstermektedir. Norm örneklemden aynı çocuklar için öğretmen ve anne baba formundan elde edilen puanlar arasındaki ilişkiler Pearson korelasyon katsayısı hesaplanarak incelenmiştir. Korelasyon değeri duyguları yönetme becerileri için .405 olarak hesaplanmıştır. Bu sonuç, çocukların duyguları yönetme becerileri değerlendirmede öğretmen ve anne babalarının değerlendirmeleri arasında orta düzeyde bir tutarlıllğı olduğu şeklinde yorumlanabilir.

\section{Çocuklar için Bakış Açısı Alma Testi (ÇBT)}

Bakış açısı alma becerisinin üç farklı boyutunu ölçmek amacıyla Aslan ve Köksal Akyol (2016) tarafından geliştirilen "Çocuklar İçin Bakış Açısı Alma" testi kullanılmıştır. Ölçme aracı, Algısal Bakış Açısı Alma, Bilişsel Bakış Açısı Alma ve Duygusal Bakış Açısı Alma olmak üzere üç alt boyuttan ve 24 maddeden oluşmaktadır. Ölçekten alınabilecek en yüksek puan “24”, en düşük puan ise “0” dır.

Çocuklar için bakış açısı testinin güvenirliği, iç tutarlılık katsayısı ve test-tekrar test güvenirlik katsayısı hesaplanarak incelenmiştir. İç tutarlık güvenirliği için KR-20 katsayısı 71 olarak hesaplanmıştır. Test-tekrar test güvenirliği ise .91 olarak saptanmıştır. Sonuç olarak, ÇBT'nin okul öncesi dönem üç, dört ve beş yaş çocuklarının bakış açısı alma becerilerini ölçmede geçerli ve güvenilir bir ölçme aracı olduğu belirlenmiştir (Aslan \& Köksal Akyol, 2016).

\section{Deneysel İşlem}

DYBEP'nin geliştirilmesi aşamasında duyguları yönetme becerilerine yönelik alanyazın taranmıştır. Ardından Milli Eğitim Bakanlığı tarafından hazırlanan 2013 Okul Öncesi Eğitim Programı ve Okul Öncesi Eğitimde Sosyal Beceri Değerlendirme Ölçeğinin (OSBED) Duyguları Yönetme Alt Ölçeğinden duyguları yönetme becerilerine yönelik kazanım-göstergeler incelenmiştir. İncelemeler sonucunda, uygun olan kazanımlar bir araya getirilerek eğitim programına alınmıştır. 
Hazırlanan kazanım ve göstergeler alan uzmanlarına gönderilmiştir. Alan uzmanlarına yollanan form değerlendirirken duyguları yönetme becerileri konusunda maddelerin uygun olup olmadığı değerlendirilmiştir. Alan uzmanları kendilerine yollanan 19 kazanım ve 60 göstergeden oluşan formları duygularını yönetme becerilerini geliştirmede uygun olup olmadığı düşünerek gerekli düzeltmeleri yapmıştır. Sonuçta 17 kazanım ve 53 gösterge olarak kazanım ve göstergelere son hale getirilmiştir.

DYBEP literatür araştırılarak, belirlenen kazanım ve göstergeler doğrultusunda, çocukların gelişim düzeyleri ve bireysel farklılıkları göz önünde bulundurularak yazılmıştır. Eğitim programının oluşturulmasında yakından uzağa, bilinenden bilinmeyene, basitten zora, somuttan soyuta ilkelerine dikkat edilmiştir.

Her etkinlik planı; Etkinlik adı, etkinlik türü, kazanım ve göstergeler, materyaller, kavramlar ve sözcükler, dikkat edilecek noktalar, aile katılımı, öğrenme süreci ve değerlendirme süreci alt başlıklarından oluşmaktadır.

Eğitim programında Türkçe, Sanat, Matematik, Fen, Okuma-Yazmaya Hazırlık, Müzik, Oyun, Hareket, Drama, Alan Gezisi gibi etkinliklere yer verilmiştir. Her bir eğitim durumunda en az iki farklı etkinlik bulunmaktadır. Eğitim programında pasif ve hareketli etkinliklere, etkinlik çeşitlerine ve etkinliğin uygulandığı yere ve etkinliklere ayrılan sürenin dengeli bir şekilde ayarlanmasına dikkat edilmiştir. Çocukların etkinliklere katılımlarını kolaylaştırmak için günlük yaşam deneyimlerinden yararlanılmaya çalışılmıştır.

Eğitim programı hazırlandıktan sonra, değerlendirmek üzere üç uzmana gönderilmiştir. Alan uzmanlarından etkinliklerin uygulanması, kazanım ve göstergelere uygunluğu, kullanılacak materyaller, uygulama süresinin yeterliğini değerlendirmeleri istenmiştir. Uzman görüşleri doğrultusunda son şekli oluşturulmuştur.

Daha sonra kazanım ve göstergeler eğitimin yapılacağı 12 haftaya dağıtılmıştır. Dağıtım yapılırken; verilecek eğitimin haftada 2 gün olmak üzere 12 hafta süreceği düşünülerek kazanımlar basitten zora doğru olacak şekilde haftalara yayılmıştır. Kazanım ve göstergeler 24 etkinliği içerecek şekilde tablolaştırılmıştır. Bütün kazanım ve göstergeler eğitim programı içerisine eşit olarak dağıtılmıştır.

Hazırlanan eğitim programı deney grubuna 12 hafta ve 24 oturumdan oluşmuştur. Araştırmacı tarafından 30 Eylül-27 Aralık 2019 tarihleri arasında haftada 2 gün öğlenleri uygulanmıştır. Deney grubuna eğitim programı uygulanırken, kontrol grubundaki çocuklara normal eğitim programı uygulanmıştır.

Uygulama süreci başlamadan önce ailelere eğitim programının içeriğini ve tarihlerini gösteren etkinlik çizelgesi dağıtılmıştır. Anne ve babalardan çocukları desteklemeleri ve hedeflenen becerileri 
içselleştirmelerini sağlayacak gerçek yaşamdan tecrübeler sunmaları istenmiştir (Örneğin, Korku duygusuna yönelik çocuğun anne babasını korkutan olayların neler olduğunu öğrenip resimlerini sınıfta paylaşması gibi).

Araştırmacı etkinliklere başlamadan önce deney grubuna o günkü eğitim akışına göre sınıf ortamı düzenlenmiştir. Eğitim programı çocukların eğitimlerine devam ettikleri sınıflarında uygulanmıştır. Eğitim ortamı çocukların etkinliklere karşı merak uyandıracak görsel materyallerle ve kendilerini güvende hissedebilecekleri şekilde oluşturulmuştur. Etkinliklerde kullanılacak materyaller ve araç-gereçler araştırmacı tarafından uygulama sınıfına getirilmiştir. Çocuklar kahvaltılarını yaptıktan sonra sınıfa girişleri ile etkinliklere başlanılmıştır.

Etkinlikler küçük grup etkinlikleri ve büyük grup etkinlikleri şeklinde gerçekleştirilmiştir. Etkinlikler sırasında çocukların aktif katılımı için soru-cevap, gösteri yöntemi, küçük grup tartışması, büyük grup tartışması, beyin fırtınası, drama gibi öğrenme yöntemlerinden yararlanılmıştır. Küçük grup çalışmalarında mümkün olduğunca her çocuğun kendini ifade etmesine önem verilmiştir.

Her etkinlikte kazanım ve göstergelere yönelik sorular sorulmuş, çocukların yanıtlarına uygun geri bildirimler verilerek gerekli açıklamalar yapılmıştır. Tüm etkinliklerin tamamlanmasının ardından günü değerlendirme zamanında çocukların kazanım ve göstergelere ulaşma düzeyi ve etkinlikler hakkındaki görüşleri dikkate alınarak daha kapsamlı bir değerlendirme yapılmıştır. Uygulama sırasında etkinlikle ilgili fotoğraf çekimi yapılmıştır.

\section{Verilerin Analizi}

Anasınıfına devam eden çocuklara uygulanan "Duyguları Yönetme Becerileri Alt Ölçeği", "Çocuklar İçin Bakış Açısı Alma Ölçeği” ve “Genel Bilgi Formu” aracılığıyla toplanan veriler SPSS-24 paket programına işlenmiştir. Normallik testi sonuçlarına göre deney ve kontrol grubunda bulunan çocukların duyguları yönetme becerilerindeki ölçümlerin Shapiro-Wilk istatistiklerinin p<,05'e göre normallik varsayımını karşıladığı yani normal dağılım sergilediği görülmektedir. Algısal bakış açısı alma, bilişsel bakış açısı alma, duygusal bakış açısı alma alt faktörlerinde ve çocuklar için bakış açısı alma ölçeğinin genelinde deney ve kontrol grubunda bulunan çocukların ölçümlerinin p<,05'e göre normallik varsayımını sağlamadığı yani normal dağılım sergilemediği görülmektedir. Test varyanslarının ise Levene homojenlik test sonuçları $\mathrm{p}<, 05^{\prime}$ e göre bütün ölçümlerde homojen olduğu görülmektedir.

Deney ve kontrol gruplarında bulunan çocukların duyguları yönetme beceri ölçümlerine ait farklılıkların karşılaştııılmasında öntest puanları, sontest puanları ve sontest-öntest fark puanları arasındaki farklılığa Independent-Samples (Bağımsız Örneklemler) t-Testi ile bakılmıştır. Deney 
grubunda yer alan çocukların kalıcılık puanları ile sontest puanları arasındaki anlamlı farklılığa Paired-Samples (Eşleştirilmiş Örneklemler) t-Testi analizi ile bakılmıştır.

Okul öncesi dönem çocuklarının öntest uygulaması, sontest uygulaması, sontest öntest fark puanları ve deney grubunun kalıcılık puanlarına ilişkin hesaplanan ortalama değerlerin karşılaştırılmasından algısal bakış açısı alma, bilişsel bakış açısı alma, duygusal bakış açısı alma alt faktörlerinde ve çocuklar için bakış açısı alma ölçeğinin geneline ilişkin ölçümlerde nonparametrik istatistik teknikleri kullanılmıştır. Bu alt faktörlerde ve ölçeğin genelinde deney ve kontrol gruplarında bulunan çocukların öntest puanları, sontest puanları ve sontest-öntest fark puanları arasındaki farklılığa Mann-Whitney U Testi ile bakılmıştır. Deney grubunda yer alan çocukların kalıcılık puanları ile sontest puanları arasındaki anlamlı farklılığa Wilcoxon işaretli sıralar testi analizi ile bakılmıştır.

\section{Bulgular}

DYBEP'nin geliştirilmesi ve bu programın anasınıfına devam eden çocukların duyguları yönetme ve bakış açısı alma becerileri üzerindeki etkisi incelenmiştir.

DYBEP'nin Deney ve Kontrol Grubunda Yer Alan Çocukların Duyguları Yönetme Becerileri

\section{Üzerindeki Etkisi}

Deney grubu öğrencilerinin DYBEP ön test puanlarının analizine ilişkin bulgular Tablo 1'de gösterilmektedir.

Tablo 2. Deney ve Kontrol Grubu OSBED-DYBÖ Ön Test Puanları t-Testi Sonuçları

\begin{tabular}{cllccccc} 
& Grup & $\mathbf{N}$ & $\overline{\mathbf{X}}$ & $\mathbf{S}$ & $\mathbf{t}$ & $\mathbf{s d}$ & $\mathbf{p}$ \\
\hline $\begin{array}{c}\text { Duyguları Yönetme } \\
\text { Becerileri }\end{array}$ & Deney & 20 & 39,35 & 7,71 & & & \\
& Kontrol & 20 & 36,30 & 6,86 & & &
\end{tabular}

Tablo 2 incelendiğinde, deney grubunda bulunan çocukların duyguları yönetme beceri puanları $(\overline{\mathrm{X}}=39,35)$ ile kontrol grubunda bulunan çocukların duyguları yönetme beceri puanları $(\bar{X}=36,30)$ arasında $t_{(38)}=1,68, p=, 100>, 05$ 'e göre anlamlı farklılık olmadığı yani grupların eğitim programı öncesi duyguları yönetme becerisi bağlamında birbirine denk oldukları görülmektedir.

Tablo 3. Deney ve Kontrol Grubu OSBED-DYBÖ Son Test Puanları t-Testi Sonuçları

\begin{tabular}{clcccccc} 
& Grup & $\mathbf{N}$ & $\overline{\mathbf{X}}$ & $\mathbf{S}$ & $\mathbf{t}$ & sd & $\mathbf{p}$ \\
\hline & Deney & 20 & 42,00 & 7,32 & & & \\
$\begin{array}{c}\text { Duyguları Yönetme } \\
\text { Becerileri }\end{array}$ & Kontrol & 20 & & & 2,86 & 38 &, $007^{*}$ \\
& & & 36,70 & 3,88 & & &
\end{tabular}

${ }^{*} \mathrm{p}<, 05$ 
Tablo 3 incelendiğinde, deney grubunda bulunan çocukların duyguları yönetme beceri puanları $(\bar{X}=42,00)$ ile kontrol grubunda bulunan çocukların duyguları yönetme beceri puanları $(\bar{x}=36,70)$ arasında $t_{(38)}=2,86, p=, 007<, 05^{\prime}$ e göre anlamlı farklılık olduğu görülmektedir. Bu anlamlı farklılık, deney grubunda bulunan çocuklara uygulanan duyguları yönetme becerileri eğitim programının çocukların duyguları yönetme beceri puanlarını kontrol gruplarında yer alan çocukların beceri puanlarına göre anlamlı farklılık yaratacak düzeyde arttırdığından kaynaklanmaktadır.

Tablo 4. Deney ve Kontrol Grubu OSBED-DYBÖ Ön Test ve Son Test Fark Puanları t-Testi Sonuçları

\begin{tabular}{clcccccc} 
& Grup & $\mathbf{N}$ & $\overline{\mathbf{X}}$ & $\mathbf{S}$ & $\mathbf{t}$ & $\mathbf{s d}$ & $\mathbf{p}$ \\
\hline $\begin{array}{c}\text { Duyguları Yönetme } \\
\text { Becerileri }\end{array}$ & Deney & 20 & 2,65 & 2,43 & & & \\
& Kontrol & 20 & & & 3,15 & 38 &, $003^{*}$ \\
& & & 0,40 & 2,06 & & &
\end{tabular}

${ }^{*} \mathrm{p}<, 05$

Tablo 4 incelendiğinde, deney grubunda bulunan çocukların duyguları yönetme beceri gelişim düzeyine ait fark puanları $(\bar{X}=2,65)$ ile kontrol grubunda bulunan çocukların duyguları yönetme beceri gelişim düzeyine ait fark puanları $(\bar{X}=0,40)$ arasında $t_{(38)}=3,15, p=, 003<, 05$ 'e göre anlamlı farklılık olduğu görülmektedir. Bu anlamlı farklılık, deney grubunda bulunan çocuklara uygulanan duyguları yönetme becerileri eğitim programının çocukların duyguları yönetme becerilerine ait gelişim düzeyi puanlarını kontrol gruplarında yer alan çocukların becerilerine ait gelişim düzeyi puanlarına göre anlamlı farklılık yaratacak düzeyde arttırdığından kaynaklanmaktadır.

Tablo 5. Deney Grubu OSBED-DYBÖ Son Test Puanları ile Kalıcılık Testi Puanları t-Testi Sonuçları

\begin{tabular}{clcccccc} 
& Test & $\mathbf{N}$ & $\overline{\mathbf{X}}$ & $\mathbf{S}$ & $\mathbf{t}$ & sd & $\mathbf{p}$ \\
\hline $\begin{array}{c}\text { Duyguları Yönetme } \\
\text { Becerileri }\end{array}$ & Son Test & 20 & 42,00 & 7,32 & & & \\
& Kalıcılık Testi & 20 & 41,90 & 7,10 & & &
\end{tabular}

Tablo 5 incelendiğinde, deney grubunda bulunan çocukların duyguları yönetme beceri son test puanları $(\bar{X}=42,00)$ ile Deney grubunda bulunan çocukların duyguları yönetme beceri kalıcılık testi puanları $(\bar{X}=41,90)$ arasında $t_{(19)}=0,57, p=, 577>, 05$ 'e göre anlamlı farklılık olmadığı görülmektedir. Deney grubunda bulunan çocuklara uygulanan duyguları yönetme becerileri eğitim programının belirli bir zaman geçtikten sonrada duyguları yönetme becerileri üzerinde etkisinin devam ettiği yani kazanılan becerilerin zamana bağlı olarak değişmediği görülmektedir.

Duyguları Yönetme Becerileri Eğitimi Programının Deney ve Kontrol Grubunda Yer Alan Çocukların Bakış Açısı Alma Becerileri Üzerindeki Etkisine İlişkin Bulgular 
Tablo 6. Deney ve Kontrol Grubu ÇBT Ölçeği Ön Test Puanları Mann-Whitney U Testi Sonuçları

\begin{tabular}{|c|c|c|c|c|c|c|c|c|}
\hline Öntest & Grup & $\mathbf{N}$ & $\bar{x}$ & s & Sira Ort. & Sira Top. & $\mathrm{U}$ & p \\
\hline \multirow{2}{*}{ Algısal Bakış Açısı Alma } & Deney & 20 & 3,05 & 1,15 & 17,75 & 355,00 & \multirow{2}{*}{145,00} & \multirow{2}{*}{,094 } \\
\hline & Kontrol & 20 & 3,60 & 0,68 & 23,25 & 465,00 & & \\
\hline \multirow{2}{*}{ Bilişsel Bakış Açısı Alma } & Deney & 20 & 0,35 & 1,09 & 19,63 & 392,50 & \multirow{2}{*}{182,50} & \multirow{2}{*}{,446 } \\
\hline & Kontrol & 20 & 0,45 & 1,05 & 21,38 & 427,50 & & \\
\hline \multirow{2}{*}{$\begin{array}{l}\text { Duygusal } \\
\text { Alma }\end{array}$} & Deney & 20 & 7,35 & 2,68 & 12,73 & 354,50 & \multirow{2}{*}{144,50} & \multirow{2}{*}{ 131 } \\
\hline & Kontrol & 20 & 8,60 & 2,39 & 23,28 & 465,50 & & \\
\hline \multirow{2}{*}{$\begin{array}{l}\text { Çocuklar İçin Bakış Açısı } \\
\text { Alma Ölçeği }\end{array}$} & Deney & 20 & 10,75 & 3,71 & 17,55 & 351,00 & \multirow{2}{*}{141,00} & \multirow{2}{*}{ 109 } \\
\hline & Kontrol & 20 & 12,65 & 3,43 & 23,45 & 469,00 & & \\
\hline
\end{tabular}

${ }^{*} \mathrm{p}<, 05$

Tablo 6' da görüldüğü gibi algısal bakış açısı alma alt faktörüne ait deney grubunda yer alan çocukların ön test puanlarına $(3,05)$ ait sıra ortalamaları $(17,75)$ ile kontrol grubunda yer alan çocukların ön test puanlarına $(3,60)$ ait sıra ortalamaları $(23,25)$ arasında $U=145,00, p=, 094>, 05$ 'e göre anlamlı farklılık olmadığı yani deney ve kontrol grubunda bulunan çocukların algısal bakış açısı alma becerilerinin denk olduğu görülmektedir. Bilişsel bakış açısı alma alt faktörüne ait deney grubunda yer alan çocukların ön test puanlarına $(0,35)$ ait sıra ortalamaları $(19,63)$ ile kontrol grubunda yer alan çocukların ön test puanlarına $(0,45)$ ait sıra ortalamaları $(21,38)$ arasında $U=182,50, p=, 446>, 05$ 'e göre anlamlı farklılık olmadığı yani deney ve kontrol grubunda bulunan çocukların bilişsel bakış açısı alma becerilerinin denk olduğu görülmektedir. Duygusal bakış açısı alma alt faktörüne ait deney grubunda yer alan çocukların ön test puanlarına $(7,35)$ ait sıra ortalamaları $(12,73)$ ile kontrol grubunda yer alan çocukların ön test puanlarına $(8,60)$ ait sıra ortalamaları $(23,28)$ arasında $U=144,50, p=, 131>, 05^{\prime}$ e göre anlamlı farklılık olmadığı yani deney ve kontrol grubunda bulunan çocukların duygusal bakış açısı alma becerilerinin denk olduğu görülmektedir. Çocuklar için bakış açısı alma ölçeğinin geneline ilişkin deney grubunda yer alan çocukların ön test puanlarına $(10,75)$ ait sıra ortalamaları $(17,55)$ ile kontrol grubunda yer alan çocukların ön test puanlarına $(12,65)$ ait sıra ortalamaları $(23,45)$ arasında $U=141,00$, p=,109>,05’e göre anlamlı farklılık olmadığ yani deney ve kontrol grubunda bulunan çocukların bakış açısı alma becerilerinin denk olduğu görülmektedir.

Tablo 7. Deney ve Kontrol Grubu ÇBT Ölçeği Son Test Puanları Mann-Whitney U Testi Sonuçları

\begin{tabular}{clccccccc} 
Sontest & Grup & $\mathbf{N}$ & $\overline{\mathbf{X}}$ & $\mathbf{S}$ & Sıra Ort. & Sıra Top. & U & p \\
\hline \multirow{2}{*}{ Algısal Bakış Açısı Alma } & Deney & 20 & 3,40 & 0,88 & 18,38 & 367,50 & & \\
& Kontrol & 20 & 3,75 & 0,55 & 22,63 & 452,50 & 157,50 & \multirow{2}{*}{154} \\
\hline \multirow{2}{*}{ Bilişsel Bakış Açısı Alma } & Deney & 20 & 0,90 & 1,17 & 21,00 & 420,00 & & \\
& Kontrol & 20 & 0,75 & 1,01 & 20,00 & 400,00 & 190,00 & \multirow{2}{*}{769} \\
\hline
\end{tabular}




\begin{tabular}{|c|c|c|c|c|c|c|c|c|}
\hline \multirow{2}{*}{$\begin{array}{l}\text { Duygusal Bakış Açısı } \\
\text { Alma }\end{array}$} & Deney & 20 & 10,00 & 1,95 & 23,20 & 464,00 & \multirow{2}{*}{146,00} & \multirow{2}{*}{ 139 } \\
\hline & Kontrol & 20 & 8,80 & 2,46 & 17,80 & 356,00 & & \\
\hline \multirow{2}{*}{$\begin{array}{l}\text { Çocuklar İçin Bakış Açısı } \\
\text { Alma Ölçeği }\end{array}$} & Deney & 20 & 14,30 & 3,18 & 22,20 & 444,00 & \multirow{2}{*}{166,00} & \multirow{2}{*}{ 355 } \\
\hline & Kontrol & 20 & 13,30 & 3,23 & 18,80 & 376,00 & & \\
\hline
\end{tabular}

Tablo 7'de deney grubunda bulunan çocukların duyguları yönetme becerileri eğitim programı başladıktan sonra deney ve kontrol grubunda yer alan çocukların algısal, bilişsel, duygusal ve toplam bakış açısı alma becerileri sontest puanları arasında farklılık olup olmadığı incelenmiştir. Algısal Bakış Açısı Alma alt faktörüne ait deney grubunda yer alan çocukların son test puanlarına $(\bar{X}=3,40)$ ait sıra ortalamaları $(18,38)$ ile kontrol grubunda yer alan çocukların son test puanlarına $(\bar{X}=3,75)$ ait sıra ortalamaları $(22,63)$ arasında $U=157,50, p=, 154>, 05$ 'e göre anlamlı farklılık olmadığı yani deney ve kontrol grubunda bulunan çocukların algısal bakış açısı alma becerilerinin denk olduğu görülmektedir. Bilişsel bakış açısı alma alt faktörüne ait deney grubunda yer alan çocukların son test puanlarına $(\bar{X}=0,90)$ ait sıra ortalamaları $(21,00)$ ile kontrol grubunda yer alan çocukların son test puanlarına $(\bar{X}=0,75)$ ait sira ortalamaları $(20,00)$ arasında $U=190,00, p=, 769>, 05$ 'e göre anlamlı farklılık olmadığı yani deney ve kontrol grubunda bulunan çocukların bilişsel bakış açısı alma becerilerinin denk olduğu görülmektedir. Duygusal bakış açısı alma alt faktörüne ait deney grubunda yer alan çocukların sontest puanlarına $(\bar{X}=10,00)$ ait sıra ortalamaları $(23,20)$ ile kontrol grubunda yer alan çocukların sontest puanlarına $(\bar{X}=8,80)$ ait sıra ortalamaları $(17,80)$ arasında $U=146,00, p=, 139>, 05$ 'e göre anlamlı farklılık olmadığı yani deney ve kontrol grubunda bulunan çocukların duygusal bakış açısı alma becerilerinin denk olduğu görülmektedir. Çocuklar için bakış açısı alma ölçeğinin geneline ilişkin deney grubunda yer alan çocukların sontest puanlarına $(\bar{X}=14,30)$ ait sıra ortalamaları $(22,20)$ ile kontrol grubunda yer alan çocukların sontest puanlarına $(\bar{X}=13,30)$ ait sıra ortalamaları $(18,80)$ arasında $U=166,00, p=, 355>, 05$ 'e göre anlamlı farklılık olmadığı yani deney ve kontrol grubunda bulunan çocukların son uygulamada bakış açısı alma becerilerinin genelinin denk olduğu görülmektedir.

Tablo 8. Deney ve Kontrol Grubu ÇBT Ölçeği Ön Test ve Son Test Fark Puanları Mann-Whitney U Testi Sonuçları

\begin{tabular}{|c|c|c|c|c|c|c|c|c|}
\hline Sontest-Öntest Fark Puanları & Grup & $\mathbf{N}$ & $\bar{x}$ & $\mathrm{~s}$ & Sira Ort. & Sira Top. & $\mathbf{U}$ & p \\
\hline \multirow{2}{*}{ Algısal Bakış Açısı Alma } & Deney & 20 & 0,35 & 0,88 & 22,23 & 444,50 & \multirow{2}{*}{165,50} & \multirow{2}{*}{,233 } \\
\hline & Kontrol & 20 & 0,15 & 0,37 & 18,78 & 375,50 & & \\
\hline \multirow{2}{*}{ Bilişsel Bakış Açısı Alma } & Deney & 20 & 0,55 & 0,76 & 21,95 & 439,00 & \multirow{2}{*}{171,00} & \multirow{2}{*}{,350 } \\
\hline & Kontrol & 20 & 0,30 & 0,47 & 19,05 & 381,00 & & \\
\hline \multirow{2}{*}{ Duygusal Bakış Açısı Alma } & Deney & 20 & 2,65 & 1,39 & 29,35 & 587,00 & \multirow{2}{*}{23,00} & \multirow{2}{*}{, $000^{*}$} \\
\hline & Kontrol & 20 & 0,20 & 0,77 & 11,85 & 233,00 & & \\
\hline \multirow{2}{*}{$\begin{array}{l}\text { Çocuklar İçin Bakış Açısı } \\
\text { Alma Ölçeği }\end{array}$} & Deney & 20 & 3,55 & 2,12 & 28,33 & 566,50 & \multirow{2}{*}{43,50} & \multirow{2}{*}{, $000^{*}$} \\
\hline & Kontrol & 20 & 0,65 & 1,04 & 12,68 & 253,50 & & \\
\hline
\end{tabular}


${ }^{*} \mathrm{p}<, 05$

Tablo 8'e bakıldığında algısal bakış açısı alma alt faktörüne ait deney grubunda yer alan çocukların son test-ön test fark puanlarına $(0,35)$ ait sıra ortalamaları $(22,23)$ ile kontrol grubunda yer alan çocukların son test-ön test fark puanlarına $(0,15)$ ait sıra ortalamaları $(18,78)$ arasında $U=165,50$, $\mathrm{p}=, 233>, 05$ 'e göre anlamlı farklılık olmadığı yani deney ve kontrol grubunda bulunan çocukların algısal bakış açısı alma becerilerinin gelişim düzeylerine ilişkin puanlarının denk olduğu görülmektedir. Bilişsel bakış açısı alma alt faktörüne ait deney grubunda yer alan çocukların son testön test fark puanlarına $(0,55)$ ait sıra ortalamaları $(21,95)$ ile kontrol grubunda yer alan çocukların son test-ön test fark puanlarına $(0,30)$ ait sira ortalamaları $(19,05)$ arasında $U=171,00, p=, 350>, 05$ 'e göre anlamlı farklılık olmadığı yani deney ve kontrol grubunda bulunan çocukların bilişsel bakış açısı alma becerilerinin gelişim düzeylerine ait puanlarının denk olduğu görülmektedir. Duygusal bakış açısı alma alt faktörüne ait deney grubunda yer alan çocukların son test-ön test fark puanlarına $(2,65)$ ait sıra ortalamaları $(29,35)$ ile kontrol grubunda yer alan çocukların son test-öntest fark puanlarına $(0,20)$ ait sıra ortalamaları $(11,85)$ arasında $U=23,00, p=, 000<, 05^{\prime}$ e göre anlamlı farklılık olduğu yani deney grubuna uygulanan eğitim programı sonrası duygusal bakış açısı alma becerilerine ilişkin gelişim düzeyi puanlarının kontrol grubunda yer alan çocukların duygusal bakış açısı alma becerilerine ilişkin gelişim düzeyi puanlarından daha büyük olmasından dolayı anlamlı farklılık olduğu görülmektedir. Çocuklar için bakış açısı alma ölçeğine ait deney grubunda yer alan çocukların son test-ön test fark puanlarına $(3,55)$ ait sıra ortalamaları $(28,33)$ ile kontrol grubunda yer alan çocukların son test-ön test fark puanlarına $(0,65)$ ait sıra ortalamaları $(12,68)$ arasında $U=43,50, p=, 000<, 05$ 'e göre anlamlı farklılık olduğu yani deney grubuna uygulanan eğitim programı sonrası çocuklar için bakış açısı alma becerilerine ilişkin gelişim düzeyi puanlarının kontrol grubunda yer alan çocuklar için bakış açısı alma becerilerine ilişkin gelişim düzeyi puanlarından daha büyük olmasından dolayı anlamlı farklılık olduğu görülmektedir.

Tablo 9. Deney Grubu ÇBT Ölçeği Son Test Puanları ile Kalıcılık Testi Puanları Wilcoxon İşaretli Sıralar Testi Sonuçları

\begin{tabular}{|c|c|c|c|c|c|c|c|c|}
\hline Deney Grubu & Test & $\mathbf{N}$ & $\bar{x}$ & $S$ & $\begin{array}{l}\text { Sira } \\
\text { Ort. }\end{array}$ & $\begin{array}{l}\text { Sira } \\
\text { Top. }\end{array}$ & $\mathbf{z}$ & $\mathbf{p}$ \\
\hline \multirow{2}{*}{ Algısal Bakış Açısı Alma } & Son Test & 20 & 3,40 & 0,88 & 0,00 & 0,00 & \multirow{2}{*}{$-1,00$} & \multirow{2}{*}{317} \\
\hline & Kalıcılık Testi & 20 & 3,55 & 0,69 & 1,00 & 1,00 & & \\
\hline \multirow{2}{*}{ Bilişsel Bakış Açısı Alma } & Son Test & 20 & 0,90 & 1,17 & 2,50 & 5,00 & \multirow{2}{*}{0,00} & \multirow{2}{*}{1,00} \\
\hline & Kalıcılık Testi & 20 & 0,90 & 1,25 & 2,50 & 5,00 & & \\
\hline \multirow{2}{*}{$\begin{array}{l}\text { Duygusal Bakış Açısı } \\
\text { Alma }\end{array}$} & Son Test & 20 & 10,00 & 1,95 & 2,50 & 5,00 & \multirow{2}{*}{$-0,71$} & \multirow{2}{*}{,480 } \\
\hline & Kalıcılık Testi & 20 & 10,10 & 1,62 & 3,33 & 10,00 & & \\
\hline \multirow{2}{*}{$\begin{array}{l}\text { Çocuklar İçin Duygusal } \\
\text { Bakış Açısı Alma Ölçeği }\end{array}$} & Son Test & 20 & 14,30 & 3,18 & 4,00 & 12,00 & \multirow{2}{*}{$-1,31$} & \multirow{2}{*}{ 190 } \\
\hline & Kalıcılık Testi & 20 & 14,55 & 2,80 & 5,50 & 33,00 & & \\
\hline
\end{tabular}


Tablo 9' da algısal bakış açısı alma alt faktörüne ait deney grubunda yer alan çocukların sontest puanlarına $(\overline{\mathrm{X}}=3,40)$ ait sıra ortalamaları $(0,00)$ ile deney grubunda yer alan çocukların kalıcılık testi puanlarına $(\bar{X}=3,55)$ ait sıra ortalamaları $(1,00)$ arasında $z=-1,00, p=, 317>, 05^{\prime}$ e göre anlamlı farklılık olmadığı yani deney grubunda bulunan çocukların algısal bakış açısı alma becerilerine ait son test puanları ile kalıcılık testi puanlarının birbirilerine denk olduğu görülmektedir. Bilişsel Bakış Açısı Alma alt faktörüne ait deney grubunda yer alan çocukların sontest puanlarına $(\bar{X}=0,90)$ ait sıra ortalamaları $(2,50)$ ile deney grubunda yer alan çocukların kalıcılık testi puanlarına $(\bar{X}=0,90)$ ait sıra ortalamaları $(2,00)$ arasında $\mathrm{z}=0,00, \mathrm{p}=1,00>, 05$ 'e göre anlamlı farklılık olmadığı yani deney grubunda bulunan çocukların bilişsel bakış açısı alma becerilerine ait son test puanları ile kalıcılık testi puanlarının birbirilerine denk olduğu görülmektedir. Duygusal bakış açısı alma alt faktörüne ait deney grubunda yer alan çocukların son test puanlarına $(\bar{X}=10,00)$ ait sıra ortalamaları $(2,50)$ ile deney grubunda yer alan çocukların kalıcılık testi puanlarına $(\bar{X}=10,10)$ ait sıra ortalamaları $(3,33)$ arasında $z$ $=-0,71, \mathrm{p}=, 480>, 05^{\prime}$ e göre anlamlı farklılık olmadığı yani deney grubunda bulunan çocukların duygusal bakış açısı alma becerilerine ait son test puanları ile kalıcılık testi puanlarının birbirilerine denk olduğu görülmektedir. Çocuklar için bakış açısı alma ölçeğinin geneline ilişkin deney grubunda yer alan çocukların sontest puanlarına $(\bar{X}=14,30)$ ait sıra ortalamaları $(4,00)$ ile deney grubunda yer alan çocukların kalıcılık testi puanlarına $(\bar{X}=14,55)$ ait sıra ortalamaları $(5,50)$ arasında $z=-1,31, p=, 190>, 05^{\prime}$ e göre anlamlı farklılık olmadığı yani deney grubunda bulunan çocukların bakış açısı alma becerilerine ait son test puanları ile kalıcılık testi puanlarının birbirilerine denk olduğu görülmektedir.

\section{Tartışma ve Sonuç}

Okul öncesi eğitim alan çocukların DYBEP kapsamında araştırma sonuçları bu bölümde bulguların sıralamasına göre tartışılmıştır.

Deney grubuna uygulanan DYBEP'nin, okul öncesi çocukların duyguları yönetme becerilerinde olumlu ilerlemeler sağlayabildiği görülmektedir. Çocukların duyguları yönetme becerilerine yönelik davranış ve duyarlılık geliştirmeleri için sekiz haftayı içeren eğitim programı çeşitli etkinliklerle desteklenmiştir. DYBEP kapsamında, kendi duygularını tanıma ve ifade etme, diğer bireylerin de duygularını anlayabilme, duygusal tepkilerini ayarlayabilme, olumsuz duygularla başa çıkma hakkında bilgi ve becerileri desteklemeye yönelik etkinliklere yer verilmiştir. Eğitim programının uygulama sürecinde farklı etkinlik türleri birbiriyle bütünleştirilerek uygulanmıştır.

DYBEP kapsamında, çocuğun kendi duygularını tanıma ve ifade etme, diğer bireylerin de duygularını anlayabilme, duygusal tepkilerini ayarlayabilme, olumsuz duygularla başa çıkma hakkında bilgi ve becerileri desteklemeye yönelik etkinliklere yer verilmiştir. Bu etkinlikler verilirken eğitim programında öğrenci-öğretmen etkileşiminin yüksek olması, öğretmenin çocuklara doğru 
model olması ve aile katılımı çalışmalarının programın başarısını artırmada etkili olabilir. Aynı zamanda hikâye kitapları okurken karakterlerin duygularının vurgulanması, duygu odaklı tartışmalara yer verilmesi programın etkili olmasındaki diğer etmenlerden sayılabilir. Bu bağlamda, öğretmenin sınıfta bir olayla karşılaştığında çocukları olayın duygusal etkilerine yönelik konuşmaya teşvik etme gibi fırsat eğitimlerinin program da yer verilmesinin daha kalıcı öğrenme sağladığı belirtilmiştir (Domitrovitch, Greenberg, Kusche \& Cortes, 1999). Bu bileşenler duyguları yönetme becerileri eğitim programının başarısını artıran etmenler olabilir.

Yapılan araştırmalarda, çocukların duygusal becerilerinin gelişimine yönelik uygulanan duygu düzenleme becerileri eğitim programının duygusal beceriler üzerinde anlamlı farklılık yarattı̆̆ı görülmektedir (Daunic vd. 2013; Pür, 2014; Uğur-Ulusoy, 2018). Konu ile ilgili yapılan araştırmalar incelendiğinde, Kurki, Jarvela, Mykkanen ve Maatte'e göre (2015), çocukların duygu düzenleme becerilerini geliştirmek ve bu becerileri kullanmalarını sağlamak için öğretmenlerin okul ortamında duygu düzenleme becerilerini geliştirmede iskele görevi yapması gerektiği belirtilmiştir. Ayrıca çeşitli ülkelerde çocukların sosyal duygusal becerilerini geliştirme konusunda kapsamlı uygulanan eğitim programlarının, duygusal beceriler üzerinde etkili olduğu görülmektedir. Araştırmalar incelendiğinde, PATHS (Promoting Alternative Thinking Strategy), RULER (Recognizing-Understanding-LabelingExpressing-Regulating), Second Steps, Al's Pals: Kids Making Healthy Choices, Incredible Years Classroom Dinosaur Curriculum eğitim programları içeriğinde yer alan duyguları yönetme becerileri ile çocukların duygusal bilgi ve duygu yönetimini desteklediği tespit edilmiştir (Domitrovitch, Cortes, \& Greenberg, 2007; Low, Cook, Smolkowski \& Buntain-Ricklefs, 2015; Lynch, Geller \& Schmidt, 2004; Rivers, Tominey, Bryon \& Brackett, 2013; Webster-Stratton, Reid \& Stoolmiller; 2008). Yapılan eğitim programı çalışmalarının sonuçları değerlendirildiğinde, programın çocukların duygularını yönetme becerilerini geliştirmesi açısından, yaptığımız araştırmanın bu araştırmanın bulguları ile paralellik göstermektedir.

Durmuşoğlu Saltalı (2010) tarafından yapılan araştırmada okul öncesi dönem çocuklarına duygu eğitim programı uygulamıştır. Programa dâhil olan çocukların duygusal yüz ifadelerini tanıma, anlama ve duygusal ipuçlarını fark etme düzeylerinde artış olduğu gözlemlenmiştir. Izard, Christopher, Trentacosta, King ve Mostow (2004), yapmış oldukları çalışmalarında, duygulara odaklanan hikaye kitapları, duyguların düzenlenmesi ve kullanımı için duygu odaklı teknikler içeren eğitim programı uygulanmıştır. Çalışma sonucunda duygu düzenleme becerilerine yönelik önleme programlarının çocukların gelişimlerini büyük ölçüde etkilediğini ortaya koymuşlardır. Sonuç olarak, yapılan araştırmaların sonuçları incelendiğinde yapılan bu araştırmanın bulguları ile paralellik göstermektedir. 
Deney grubuna uygulanan eğitim programı sonrası çocuklar için bakış açısı alma becerilerine ilişkin gelişim düzeyi puanlarının kontrol grubunda yer alan çocuklar için bakış açısı alma becerilerine ilişkin gelişim düzeyi puanlarından daha büyük olmasından dolayı anlamlı farklılık olduğu görülmektedir. Grazzani ve Ornaghi (2011) okul öncesi dönem çocuklara duygulara yönelik durumlarla ilgili aktif konuşmayı içeren eğitim verilmesinin, duygu terimlerinin daha iyi anlaşılmasını ve duygusal bakış açısı geliştirme de önemli olduğu belirlenmiştir. Ünüvar (2006), yoğunlaştırılmış dil etkinliklerinin çocukların bakış açısı alma becerilerinin ilerlemesinde önemli olduğunu vurgulamıştır. Laible ve Song (2006) öykü dinlemenin ve duygusal tecrübelere yönelik diyalogların bakış açısı alma becerilerinde olumlu katkı sağladığını ifade etmişlerdir. Clements vd. (2000), çocuklara yanlış inanç eğitimi içeren olaylarla ilişkili öyküler anlatmış ve ardından açıklayıcı ifadelerde bulunmuştur. Araştırma sonucunda çocukların bilişsel bakış açısı alma becerilerini önemli ölçüde etkilediği ortaya konulmuştur. Bengtsson ve Arvidsson (2011), yürütmüş oldukları çalışmada daha gelişmiş perspektif alma becerilerinin orta düzeyde duygu düzenleme ile ilişkili olduğunu ortaya koymuştur. Ayrıca, duygu düzenleme becerileri yüksek olan çocuklarda iyi perspektif alma becerileri görülmüştür. Boylamsal analizler, iki yıllık bir süre boyunca perspektif alma becerilerinde kazanç elde eden çocukların olumsuz duygularla başetme de daha ılımlı hale geldiğini ve güçlü olumlu duyguları aşağı düzenleme yeteneklerini geliştirdiğini ortaya koymuştur. Genel bulgular, çocukların duygusal tepkileri en iyi şekilde düzenlemek için perspektif alma becerilerini kullandıkları ortaya koymuştur. Yapılan çalışma sonuçları incelendiğinde, öğretmenleri tarafından çocuklara daha fazla drama etkinlikleri, rol yapma, duyguları içeren hikâyeler hakkında aktif konuşmalar gibi etkinliklerin bakış açısı alma becerilerini desteklediği görülmüştür. Uygulanan duyguları yönetme becerileri eğitim programı kapsamında, duygu durumlarını içeren öykü çalışmaları, zenginleştirilmiş dil etkinlikleri, yaparak- yaşarak öğrenme ortamları, drama etkinlikleri gibi hususlara özen gösterilmiştir. Bu becerileri kullanarak, çocuklar duygusal ifadenin ne zaman uygun olduğunu ve duyguları sosyal bağlama uyacak şekilde nasıl ifade edeceklerini anlayabilirler. Dahası, duygularını amaçlarına bağlı olarak nasıl yönetmeleri gerektiği konusunda perspektiflerini kullanma becerilerini kullanabilirler. $\mathrm{Bu}$ uygulama sürecinin sonucunda, deney grubundaki çocukların kontrol grubundaki çocuklara göre duygusal bakış açısı alma ve toplam puanlarının anlamlı derecede yüksek olduğu sonucuna ulaşılmıştır.

\section{Öneriler}

Araştırma bulgularına dayalı olarak eğitimcilere ve araştırmacılara aşağıdaki öneriler getirilmiştir.

Bu çalışma 2019-2020 eğitim-öğretim yılında Ankara ili ile sınırlıdır. Daha geniş örneklem grubuna uygulanarak etkisi artırlabilir. DYBEP 12 hafta süre ile haftada iki gün olmak üzere uygulanmıştır. Bundan sonraki araştırmalar boylamsal desende yürütülerek duyguları yönetme 
becerileri eğitim programına katılmış çocuklar takip edilebilir ve bu eğitimin onların ileriki yaşamları üzerindeki etkisi incelenebilir.

Duyguları Yönetme Becerileri Eğitiminin çocukların akademik başarısı, iletişim becerisi, yaşam becerisi, dil gelişimi gibi alanlar üzerindeki etkisi araştırılabilir. Ailelerle bireysel görüşmeler aracılığıyla ebeveynlerin çocuklarının duyguları yönetme becerilerinde yaşadıkları güçlükler, istekleri ve ihtiyaçları tespit edilerek eğitim programları planlanabilir.

Çocukların erken yaşlardan itibaren duyguları yönetme becerilerinin desteklenmesinde en önemli faktörlerden birisi, okul öncesi öğretmenleridir. Bu bağlamda, eğitimcilere çocuklarda duyguları yönetme becerilerine yönelik hizmet içi eğitimler verilerek bilgi ve tecrübeleri desteklenebilir. Okul öncesi eğitim kurumlarında DYBEP'nin içeriği, amaçları ve materyallerine ilişkin seminerler düzenlenerek, MEB 2013 Okul Öncesi Eğitim Programıyla bütünleştirilerek kullanılması sağlanabilir. Eğitimciler duyguları tanıma ve yönetme becerilerini konu alan çocuk kitapları, yetişkin kitapları ve film listeleri oluşturabilirler. Bu materyaller aracılı̆̆ıyla ebeveynler çocukların duyguları tanımaları, ifade etmeleri ve yönetmeleri üzerine etkileşimli okuma yapabilirler. Araştırma kapsamında her hafta o hafta uygulanan etkinliğin içeriğine yönelik ailelere haber bülteni gönderilmiştir. Bu doğrultuda öğretmenler anne-babalara sosyal duygusal becerilerini geliştirmek için evde neler yapmaları gerektiğini uygun bir dille yazılarak haber mektupları aracılığıyla duyurulabilir.

\section{Kaynaklar}

Akbaba, G. (2017). Beş ve altı yaş çocuklarının duygu düzenlemesinde çocuk mizacıyla anne davranışları arasındaki etkileşimin incelenmesi. Yüksek Lisans Tezi, İstanbul Üniversitesi Eğitim Bilimleri Enstitüsü, İstanbul.

Aslan, D. ve Köksal Akyol, A. (2016). Çocuklar için bakış açısı alma testinin geliştirilmesi. Ahi Evran Üniversitesi Kırşehir Ĕ̆gitim Fakültesi Dergisi (KEFAD), 17(3), 207-221.

Ashiabi, G. (2000). Promoting the emotional development of preschoolers. Early Childhood Education Journal. 28(2), 79-84.

Astington, J. W. ve Jenkins, J. M. (1995). Theory of mind development and social understanding. Cognition and Emotion, 9(2-3), 151-165.

Bengtsson, H. ve Arvidsson, A. (2011). The impact of developing social perspective-taking skills on emotionality in middle and late childhood, Social Development, 20(2), 353-375.

Bozkurt Yükçü, S., \& Demircioğlu, H. (2017). Okul öncesi dönem çocuklarının duygu düzenleme becerilerinin çeşitli değişkenler açısından incelenmesi. Mehmet Akif Ersoy Üniversitesi Eğitim Fakültesi Dergisi, 44, 442-466. 
Caselman, T. D. ve Self, P. A. (2008). Assessment instruments for measuring young children's socialemotional behavioral development. Children and Schools, 30(2), 103-115.

Clements, W.A., Rustin, C.L. ve McCallum, S. (2000). Promoting the transition from implicit to explicit understanding: A training study of false belief. Developmental Science, 3(1), 81-92.

Daunic, A., Corbett, N., Smith, S., Barnes, T., Santiago-Poventud, L., Chalfant, P.,...Gleaton, J. (2013). Brief report: Integrating social-emotional learning with literacy instruction: An intervention for children at risk for emotional and behavioral disorders. Behavioral Disorders, 39(1), 43-51.

Dixon, A. J. ve F. Moore, C. (1990). The development of perspective taking: Understanding differences in information and weighting. Child Development, 61, 1502-1513.

Domitrovitch, C. E., Greenberg, M. T., Kusche, C., \& Cortes, R. (1999). Manual for the Preschool PATHS Curriculum. MA: Channing-Bete Company.

Domitrovitch, C. E., Cortes, R. C., \& Greenberg, M. T. (2007). Improving young children's social and emotional competence: A randomized trial of the preschool "PATHS" curriculum. The Journal of Primary Prevention, 28(2), 67-91.

Durlak, J. A., Weissberg, R. P., Dymnicki, A. B., Taylor, R. D. ve Schellinger, K. B. (2011). The impact of enhancing students' social and emotional learning: A meta-analysis of school-based universal interventions. Child Development, 82(1), 405-432.

Durmuşoğlu-Saltalı, N. (2010). Duygu Eğitimi Programı'nın okul öncesi eğitime devam eden altı yaş çocuklarının duygusal becerilerine etkisi. Doktora Tezi, Selçuk Üniversitesi Sosyal Bilimler Enstitüsü, Konya.

Ersan, C. (2017). Okul Öncesi Dönem Çocuklarının Saldırganlık Düzeylerinin Duygu Ifade Etme ve Duygu Düzenleme Açısından İncelenmesi. Doktora Tezi, Pamukkale Üniversitesi Eğitim Bilimleri Enstitüsü, Pamukkale.

Grazzani, I. ve Ornaghi, V. (2011). Emotional state talk and emotion understanding: A training study with preschool children. Journal of Child Language, 38(5), 11241139.

Greenberg, M. T. (2006). Promoting resilience in children and youth: Preventive interventions and their interface with neuroscience. Annals of the New York Academy of Science, 1094, 139-150.

Greenberg, M. T., Weissberg, R. P., O’Brien, M. U., Zins, J. E., Fredericks, L., Resnik, H., et al. (2003). Enhancingschool-based prevention and youth development through coordinated social, emotional, and academic learning. American Psychologist, 58, 466-474.

Izard, C. E., Trentacosta, C. J., King, K. A., \& Mostow, A. J. (2004). An emotion-based prevention program for Head Start children. Early Education \& Development, 15(4), 407-422. 
Kurki, K., Jarvela,S., Mykkanen, A. ve Maattä, E.(2015) Investigating children's emotion regulation in socio-emotionally challenging classroom situations. Early Child Development and Care, 185:8, $1238-1254$.

Laible, D., ve Song, J. (2006). Constructing emotional and relational understanding: The role of affect and mother-child discourse. Merrill-Palmer Quarterly, 52, 44-69.

Lewis, M. (1998). Emotional competence and development. In D. Pushkar, W. M. Bukowski, A. E. Schwartzman, D. M. Stack, \& D. R. White (Eds.), Improving competence across the lifespan: Building interventions based on theory and research (pp. 27-36). New York, NY: Plenum Press.

Low, S., Cook, R. C., Smolkowski, K., \& Buntain-Ricklefs, J. (2015). Promoting social-emotional competence: An evaluation of the elementary version of Second. Journal of School Psychology, 53(6), 463-477.

Lynch, K. B., Geller, S. R., \& Schmidt, M. G. (2004). Multi-Year Evaluation of the Effectiveness of a Resilience-Based Prevention Program for Young Children. The Journal of Primary Prevention, 24 (3), 335-353.

MEB (2013) Okul Öncesi Eğitim Genel Müdürlüğü. Okul öncesi eğitim programı (36-72 aylık çocuklar için)

Moll, H. ve Meltzoff, A.N. (2011). How does it look? Level 2 perspective-taking at 36 months of age. Child Development, 82(2), 661-673.

New, R. S. ve Cochran, M. (2007). Early Childhood Education: An International Encyclopedia, Volumes 1-4. Westport, Connecticut: Praeger.

Oswald, P. A. (2010). The effects of cognitive and affective perspective taking on empathic concern and altruistic helping. The Journal of Social Psychology, 136(5), 613-623.

Ömeroğlu, E., Büyüköztürk, Ş., Aydoğan, Y., Çakan, M., Çakmak, E. K., Özyürek, A., ... \& Yurt, Ö. (2014). Okul öncesi sosyal beceri değerlendirme ölçeği öğretmen formunun geliştirilmesi: Geçerlik ve güvenirlik analizleri. 21. Yüzyılda Eğitim ve Toplum Eğitim Bilimleri ve Sosyal Araştırmalar Dergisi, 3(8), 37-46.

Öztemür, G. (2017). The associations among executive functioning, private speech and emotion regulation in preschoolers. 18th European Conference on Developmental Psychology.

Tan-Niam, C., Wood, D. ve O'Malley, C. (1998). A cross-cultural perspective on children's theory of mind and social interaction. Early Child Development, 144, 55-67.

Trentacosta, C. J. ve Shaw, D. S. (2009). Emotional self-regulation, peer rejection, and antisocial behaviour: Developmental associations from early childhood to early adolescence. Journal of Applied Developmental Psychology, 30, 356-365. 
Uğur Ulusoy, R. (2018). Okul Öncesi Dönem Çocukları İçin Duygu Düzenleme Becerilerine Yönelik Hazırlanan Aile Kalıtıml Eğitim Programının Etkililiğinin İncelenmesi. Yüksek Lisans Tezi, Karabük Üniversitesi Sağlık Bilimler Enstitüsü, Karabük.

Ural, O., Güven, G., Sezer, T., Efe Azkeskin, K. ve Yılmaz, E. (2015). Okul öncesi dönemdeki çocukların bağlanma biçimleri ile sosyal yetkinlik ve duygu düzenleme becerileri arasındaki ilişkinin incelenmesi. Hacettepe University Faculty of Health Sciences Journal, 1(2), 589-598.

Ünüvar, G. (2006). Okul öncesi eğitim kurumlarına devam eden 4-5 Yaş çocuklarında, zenginleştirilmiş Türkçe dil etkinliklerinin bakış açısı alma becerisine ve ifade edici dil düzeylerine etkisinin incelenmesi. Yayınlanmış Yüksek Lisans Tezi. Selçuk Üniversitesi Sosyal Bilimler Enstitüsü, Konya.

Pür, I. G. (2014). Emotion regulation intervention for complex developmental trauma: Working with street children, Procedia - Social and Behavioral Sciences, 159, 697 - 701.

Rivers, S. E., Tominey, S., O' Bryon, E., \& Brackett, M. (2013). Developing emotional skills in early childhood settings using Preschool RULER. Psychological Education Review, 37, 20-25.

Roberts, W. ve Strayer, J. (1996). Empathy, emotional expressiveness, and prosocial behavior. Child Development, 67, 449-470.

Saarni, C. (1999). The development of emotional competence. New York, NY: Guilford Press.

Schaps, E., Battistich, V., \& Solomon, D. (2004). Findings from the Child Development Project. Building academic success on social and emotional learning: What does the research say?, 189.

Sessa, V. I. (1996). Using perspective taking to manage conflict and affect in teams. The Journal Of Applied Behavioral Science, 32(1), 101-115.

Staub, E. (1990). In Empathy and its development. Cambridge, England: Cambridge University Press.

Strayer, J. ve Roberts, W. (2004). Empathy and observed anger and aggression in five years old. Social Development 13 (1), 1-13.

Webster-Stratton, C., Reid, J., \& Stoolmiller, M. (2008). Preventing conduct problems and improving school readiness: evaluation of the Incredible Years Teacher and Child Training Programs in high-risk schools, Journal of Child Psychology and Psychiatry, 49(5), 471-488.

Weil, M., Hayes, S. C. ve Capurro, P. (2011). Establishing a deictic relational repertoire in young children. The Psychological Record, 61, 371-390.

\section{Extended Summary}

\section{Investigation of the Effects of the Emotion- Management Skills Education Program on the Skills of Children to Manage Emotions and Take Perspective}

The preschool period is known as an extremely important period for the development of social-emotional competence in human life. Young children need to learn to manage their emotions 
and follow the behavioral rules established by the society, in order to achieve their own goals (new \& Cochran, 2007). The emotion management skills occur through a comprehensive process of socialization that involves learning when, where, and how to show their emotions (Lefrancois, 2001).

Especially beginning from the pre-school education period, it will be useful to teach emotion management skills. The strategies for recognizing and managing emotions can easily be gained by preschool children. Some behaviors like understanding and expressing emotions, sympathy, coping with disagreements and perspective can be improved by an educational program that is prepared to support children's emotion management skills.

Perspective-taking has been described as the process of perceiving the world from the point of another's view and interpretation of meanings from another person's feelings, intentions and reactions (Selman, 1980). Perspective-taking is thought to be important in social interactions because it develops positive social behaviors. As long as people are able to guess the thoughts of others, social interactions are becoming more predictable. Therefore, they can plan their actions with their inferences about each other (Dixon \& Moore, 1990).

Perspective-taking skill is divided into three groups as perceptual- visual, cognitive, and emotional perspective (Kurdek, 1975). Perceptual-visual perspective-taking is defined as distinguishing the visual perspective of a certain visual from another person's point of view (Elekes, Varga, \& Király, 2016). Cognitive perspective-taking is defined as the ability to imagine what objects look like from another perspective (Taylor, 1988). Emotional perspective-taking occurs when an individual becomes aware of others' feelings and understands why these feelings occur (Kahchaourian, 2013). Children are able to know other people's feelings as they develop their capacity to take other people's perspective. Through this skill, people can regulate their movements by predicting their perceptions, thoughts or feelings about a particular event or object (Moll \& Meltzoff, 2011). In this context, it is seen that children's perspective-taking and emotion management skills may have different effects on social-emotional behaviors.

Thus, it is aimed to analyze the effect of Emotion Management Skills Education Program used for nursery class on children's perspective-taking and emotion management skills. The child and family general information form, the Children's Perspective Taking Test prepared by Aslan and Köksal Akyol (2016) and the emotion management skills subscale of the Preschool Social Skills Assessment Scale supported by TÜBITAK were used as data collection tools. The study group of the research consists of two classes of Celal Tarman Kindergarten, which is affiliated to the Ministry of National Education in the 2019-2020 academic year. The experimental group consists of 20 children and the control group consists of 20 children, totally 40 children. Preliminary tests were applied to the experimental group and the control group. After the program implementation in 24 sessions in 12 
weeks for two days a week, the post-test was applied to the same groups. As a result of the findings, it was concluded that the Emotion Management Skills Training Program applied to the experimental group was effective on emotion management skills and this effect was permanent. As a result of the research, it was found that there was a statistically significant difference in the emotional perspective and total scores of children in the experimental group.

According to the results of the research, Emotion Management Skills Education Program, applied to the experimental group, indicated positive improvement in the ability of preschool children's emotion management. The Emotion Management Skills Education Program involves activities supporting knowledge and skills about recognizing and expressing one's own emotions, understanding the feelings of other individuals, adjusting their emotional reactions, and coping with negative emotions. During the implementation process of the education program, different types of activities were integrated into each other. Emotional awareness and regulation skills were significantly improved with education. As a matter of fact, the results of the research to measure this skill appear to support this statement (Domitrovitch, Cortes, \& Greenberg, 2007; Kurki, Jarvela, Mykkanen \& Maatte, 2015; Low, Cook, Smolkowski \& Buntain-Ricklefs, 2015).

In our research, we concluded that emotional perspective-taking and the total scores of the children in the experimental group were significantly higher than the children in the control group. There are several researches in the literature that support this view. In their study, Bengtsson and Arvidsson (2011) found that advanced perspective-taking skills were associated with moderate levels of emotion regulation. Moreover, better perspective-taking skills have been seen in children with high emotion- regulation skills. Ünüvar (2006) emphasized that intensified language activities are important for advancing children's perspective-taking skills. Laible and Song (2006) stated that listening to stories and dialogue about emotional experiences have a positive contribution to their perspective-taking skills.

In the Emotion Management Skills Education Program, story studies involving mood states, enriched language activities, doing-living learning environments, and drama activities have been paid significant attention. By using these skills, children can understand when an emotional expression is appropriate and how to express emotions to fit the social context. Moreover, they can use their ability to use their perspective on how they should manage their emotions depending on their purpose. Thanks to these practices, improvements have been made to children's perspective-taking skills. 